\title{
QUARTZ WEATHERING IN FREEZE-THAW CYCLES: EXPERIMENT AND APPLICATION TO THE EL'GYGYTGYN CRATER LAKE RECORD FOR TRACING SIBERIAN PERMAFROST HISTORY
}

\author{
GEORG SCHWAMBORN ${ }^{1}$, LUTZ SCHIRRMEISTER ${ }^{1}$, FRANZISKA FRÜTSCH ${ }^{2}$ and \\ BERNHARD DIEKMANN ${ }^{1}$ \\ ${ }^{1}$ Alfred Wegener Institute for Polar and Marine Research, Potsdam, Germany \\ ${ }^{2}$ Institut für Geologische Wissenschaften, Freie Universität Berlin, Berlin, Germany
}

Schwamborn, G., Schirrmeister, L., Frütsch, F. and Diekmann, B. 2012. Quartz weathering in freeze-thaw cycles: experiment and application to the El'gygytgyn Crater Lake record for tracing Siberian permafrost history. Geografiska Annaler: Series A, Physical Geography, 94, ••-••. DOI: 10.1111/j.1468-0459.2012.00472.x

\begin{abstract}
The object of this study is to test the assumption that cryogenic weathering (here understood as in-situ disintegration of rock under cold-climate conditions including ice as a weathering agent) preferentially breaks up quartz grains. We apply the results of laboratory tests to a Quaternary sediment record. The combination of silt production, relative quartz enrichment in the silt fraction, and quartz grain micromorphology is traced in a multi-100-kyr lake sediment archive as indicator data for cryogenic weathering. Constant cryogenic weathering conditions are inferred for at least the last 220000 years from a lake sediment core of El'gygytgyn Crater, northeast Russia. This is the longest continuous terrestrial archive currently known for the continental Arctic.

Quartz enrichment in the fines evolves from seasonal freeze-thaw weathering as demonstrated in laboratory testing where over 100 freeze and thaw cycles crack quartz grains preferentially over feldspar. Microscopic grain features demonstrate that freeze-thaw cycling probably disrupts quartz grains along mineral impurities such as bubble trails, gas-liquid inclusions, or mineralogical subgrain boundaries. Single-grain micromorphology (e.g. angular outlines, sharp edges, microcracks, brittle surfaces) illustrates how quartz becomes fragmented due to cryogenic cracking of the grains. The single-grain features stemming from the weathering dynamics are preserved even after a grain is transported off site (i.e. in mobile slope material, in seasonal river run-off, into a lake basin) and may serve as first-order proxy data for permafrost conditions in Quaternary records.
\end{abstract}

Key words: quartz micromorphology, weathering, terrestrial Arctic

\section{Introduction}

There is a lack of continuous sediment archives that can be used to study the history of Arctic permafrost. Permafrost is usually associated with and documented in proximity to glaciated (or formerly glaciated) areas in the periglacial realm (e.g. Harris 1994; Murton 2005). Yet, little is known about the age and continuity of permafrost conditions, since permafrost is a thermal and not a stratigraphical phenomenon. Drawing an inference about permafrost history mostly relies on studying local sections that provide insights into restricted time windows, mostly of the Quaternary (Schirrmeister et al. 2002; Froese et al. 2008; Wetterich et al. 2008; Lacelle et al. 2009; Meyer et al. 2010; Reyes et al. 2010; Kanevskiy et al. 2011). More limits on studying permafrost history arise from imprecise age determinations of permafrost due to reworked or out-of-range radiocarbon material, insufficient bleaching of optical stimulated luminescence (OSL) material, or the uncertainty of postdepositional permafrost formation (Krbetschek et al. 2000; Schwamborn et al. 2002; Bateman, 2008; Schirrmeister et al. 2008; Arnold and Roberts 2011).

The study of permafrost history also suffers from a lack of suitable proxy data. Process observation of frost shattering has a long tradition (Grawe 1936; Tricart 1956) and combines both field studies and accompanying laboratory experiments. However, this method has stimulated ongoing debates about the main drivers of rock and grain break-up (e.g. Wiman 1963; Hall and Thorn 2011). The phase change from water to ice and the induced $9 \%$ volume increase as elucidated in Bridgman's (1912) pioneering statement is recognized as one prominent driving factor in cracking rock; freezing can shatter rock material by expanding fissures and cracks (McGreevy and Whalley 1985). Temperature and moisture variations can 


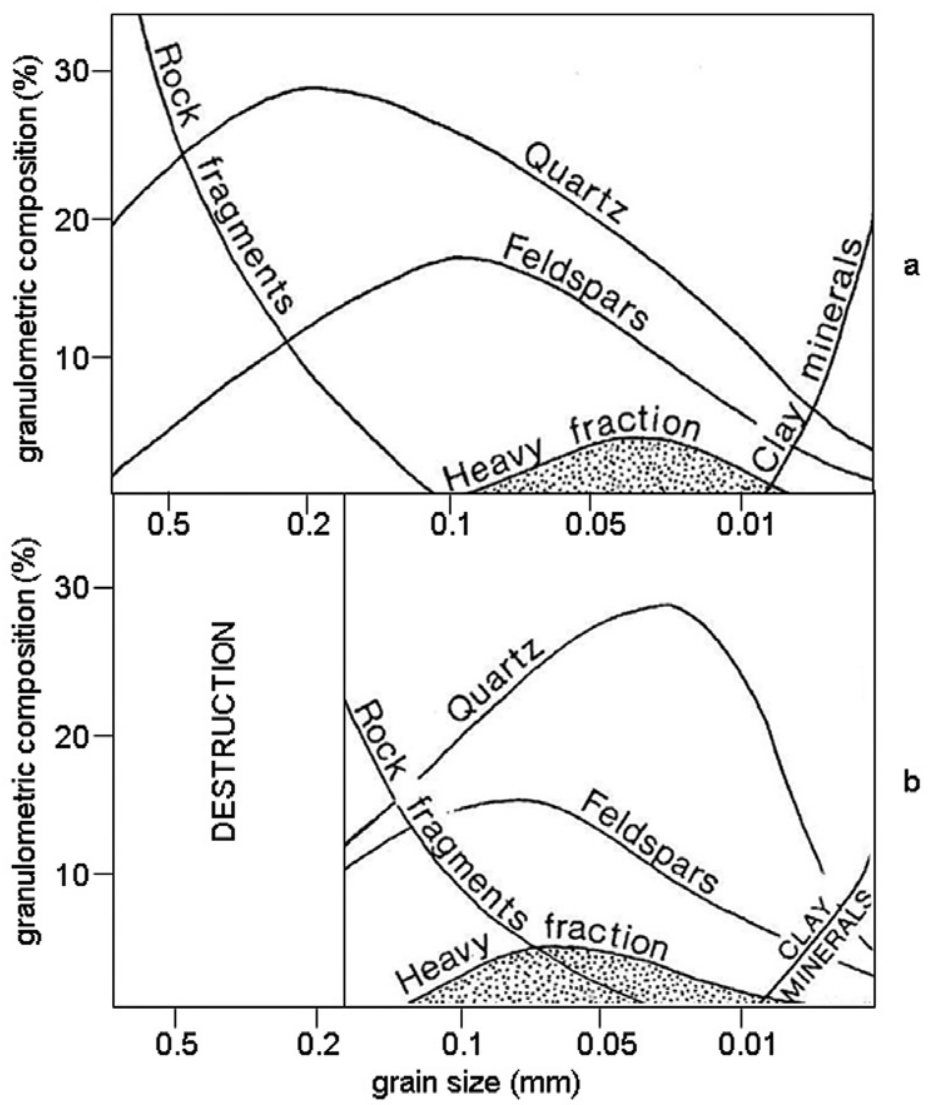

Fig. 1. A qualitative scheme of changes in the distribution of mineralogical parameters with grain size. (a) The distribution of basic mineral components of sedimentary rocks under mid latitude conditions, and (b) under cryogenic conditions (from Konishchev 1982). Note the absence of coarser sand under cryogenic conditions and quartz enrichment in the finer silt sizes.

also cause material dilation (Thomachot et al. 2005). Volumetric expansion of pore water during freezing adds to material cracking (Walder and Hallet 1986), and ice segregation at sub-zero temperatures is another productive power in cracking rocks as shown by Hallet et al. (1991) and Murton et al. (2006). Furthermore, thermal stress alone can drive rock and grain disintegration in the course of high-amplitude daily or seasonal temperature change (Hall and André 2003). Reviews on recent advances in frost weathering studies understood in a more wide-ranging way are given by Matsuoka and Murton (2008) and Hall and Thorn (2011). First insights that cryogenic weathering is mineralogically selective at the grain-scale are from Konishchev (1973). It was found that under freeze-thaw cycles quartz preferentially disintegrates in sandy samples and accumulates in the $10-50 \mu \mathrm{m}$ silt fraction (Konishchev and Rogov 1993) (Fig. 1). This is unusual and in contrast to quartz behaviour at low latitudes (Nesbitt et al. 1997). Konishchev (1982) introduced the cryogenic weathering index (CWI) that expresses relative quartz grain enrichment in the $10-50 \mu \mathrm{m}$ fine fraction rather than in the 50-100 $\mu \mathrm{m}$ coarser fraction of the same sample. Quartz proves to be less resistant than feldspar, which occurs as ubiquitously as quartz and is used as a reference mineral:

$$
\mathrm{CWI}=\left(\mathrm{Q}_{1} / \mathrm{F}_{1}\right) /\left(\mathrm{Q}_{2} / \mathrm{F}_{2}\right)
$$

where $\mathrm{Q}_{1}=$ quartz in the $10-50 \mu \mathrm{m}$ fraction, $\mathrm{F}_{1}=$ feldspar in the $10-50 \mu \mathrm{m}$ fraction, $\mathrm{Q}_{2}=$ quartz in the $50-100 \mu \mathrm{m}$ fraction and $\mathrm{F}_{2}=$ feldspar in the $50-100 \mu \mathrm{m}$ fraction. Deposits 
that have been created under permafrost conditions have values greater than 1 , indicating that cryogenic weathering was intensive (Konishchev 1999; Demitroff et al. 2007). Here, permafrost denotes for ice-bearing permafrost, where the underlying permafrost can block the drainage of the active layer provoking wet active layer conditions. The cryogenic break-up of grains is supported, because seasonal ice is available in the soil as an amplifying factor. Under those circumstances the CWI can potentially be applied to identify permafrost when studying palaeoenvironments. In fact, the CWI has been used in a few studies to identify permafrost episodes in a terrestrial Quaternary record (Konishchev 1999; Demitroff et al. 2007; French et al. 2009) or to support thermal modelling of permafrost environments (Romanovskii and Hubberten 2001).

In order to reinforce the geological significance of quartz weathering as a potential tracer of cryogenic conditions, we repeat a simple freeze-thaw experiment that includes samples of Arctic and non-Arctic origin to complement former studies that relied only on samples of permafrost origin (Konishchev 1982). We address the following questions: (1) Can quartz grain enrichment be confirmed in the silt fraction following numerous freeze-thaw cycles for samples from other (nonpermafrost) areas (i.e. non pre-cracked grains)? Quartz grain shape and surface features are imaged using scanning electron microscope (SEM) micrographs. Single quartz grain visualization using an SEM is an established means to infer environmental processes affecting grain history (Krinsley and Doornkamp 1973; Diekmann 1990; Mahaney 2002; Van Hoesen and Orndorff 2004). It includes the imaging of quartz grain micromorphology (i.e. grain shape and surface features), which has been shown to be indicative of grain features stemming from cryogenic weathering (Schwamborn etal. 2006). (2) Is quartz grain enrichment detectable in a limnic record from a permafrost area where the weathering detritus is preserved in a continuous sequence across several glacial/interglacial cycles? Hypothetically, lake sediments approximately resemble surface soil in terms of the imported minerogenic detritus. The use of lake sediment records provides a better temporal resolution of significant events in weathering dynamics than could be achieved using a chronosequence approach. (3) Is the CWI useful as an indicator of cryogenic conditions in Quaternary records?

\section{El'gygytgyn geographical setting}

The lake sediment archive is taken from El'gygytgyn Crater Lake in northeast Russia. This site has various advantages: (1) The basin was not glaciated during the Quaternary (Glushkova 2001; Niessen et al. 2007), which excludes glacial grinding as a main driver for breaking grains. (2) It currently has the longest terrestrial archive available for the Arctic and provides a unique opportunity to trace the late Cenozoic evolution of Arctic climate and the associated permafrost history (Nowaczyk et al. 2002; Brigham-Grette et al. 2007; Juschus et al. 2007; Melles et al. 2007). (3) The bedrock geology around El'gygytgyn Crater is fairly homogeneous. It is dominated by rhyolites that provide a stable background signature of eroded rocks and their mineralogical contents.

El'gygytgyn is a meteorite crater, roughly $18 \mathrm{~km}$ in diameter, which was formed $3.58 \pm$ $0.04 \mathrm{Ma}$ ago (Layer 2000) on the Chukchi Peninsula (Fig. 2). The crater rim is between 600 and $930 \mathrm{~m}$ a.s.l. in elevation, while the surface of the lake lies at $492 \mathrm{~m}$. The lake basin is bowl shaped, with a diameter of about $12 \mathrm{~km}$ and a maximum water depth of $177 \mathrm{~m}$. The area has continuous permafrost $500 \mathrm{~m}$ thick (Yershov 1998). Most of the bedrock $(c .75 \%)$ is composed of Cretaceous rhyolites (ignimbrites and tuffs) and some of the bedrock is andesitic basalts (Stone et al. 2009). Ignimbrites are porphyric containing mainly macro crystals of quartz and feldspar next to amphiboles, pyroxenes, and biotites (Belyi 1998). Macro crystals measure around $100 \mu \mathrm{m}$ and are embedded in a red to brownish microcrystalline groundmass. Fluidal texture is common. Tuffs include mainly feldspar types as macro crystals embedded in a microcrystalline green or red groundmass. Feldspar microprobe analysis indicates an overall occurrence of albite-orthoclase (microcline)-anorthite in descending order.

About 50 concentric intermittent streams drain the catchment and import detritus to the lake (Nolan and Brigham-Grette 2007). Gravel berms around the lakeshore act as intermediate sediment filters allowing coarse-grained material to pass only during high snowmelt discharge. The fairly homogeneous catchment geology and a low ratio of catchment-to-lake surface of 1.6 to 1 is thought to make the site a suitable natural laboratory for studying climate-related, long-term changes of weathering signals, for example clay minerals (Asikainen et al. 2007). 


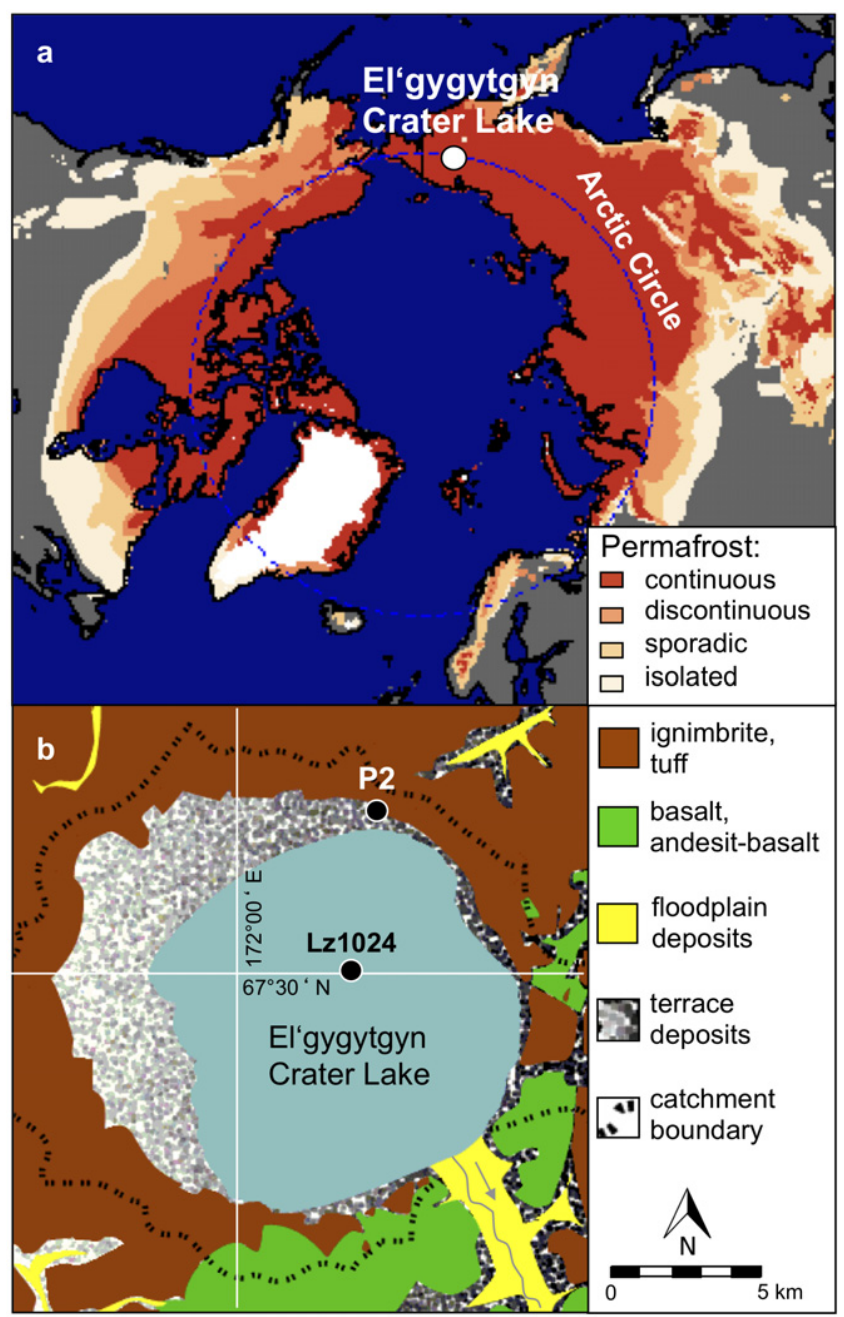

Fig. 2. Position, geological setting, and sample sites of the El'gygytgyn Crater Lake, NE Russia. (a) The Crater Lake (white dot) lies north of the Arctic Circle within the zone of continuous permafrost (map tool: nsidc.org). (b) The bedrock geology is built up of rhyolite (ignimbrites, tuffs) in the north, east, and west, and subordinated basalt in the southeast sector (simplified from Belyi and Chereshnev 1993); positions of lake core Lz1024 and permafrost core P2, which were used for this study, are shown.

\section{Material and methods}

\section{Experimental material and set-up}

The laboratory experiments were conducted using surface samples randomly collected in the field. Consequently the studied material consisted of detritus, which had already been exposed to exogene processes. Table 1 lists the eight samples that were used in the laboratory. The specimens consisted of loose multiple grains kept in evaporating dishes and the weights of the specimens varied from 18 to $125 \mathrm{~g}$. Two sediment samples (nos 1 and 2) were taken from an exposed ancient lake terrace at the southern margin of the El'gygytgyn impact crater. The basin contains mineralogical detritus from a catchment of volcanic rocks (Fig. 2). The sedimentary sample was extracted from the active layer (i.e. from the seasonally frozen soil surface) of a section that is exposed at the southern bluff of the lake. Sample no. 3 was obtained from a modern inlet stream entering El' gygytgyn Crater Lake from the west. The sample location was a small fan-like deposition in the creek mouth that measured several meters in length and width. Mineral grains in the sand-sized fraction are released from ignimbrites 


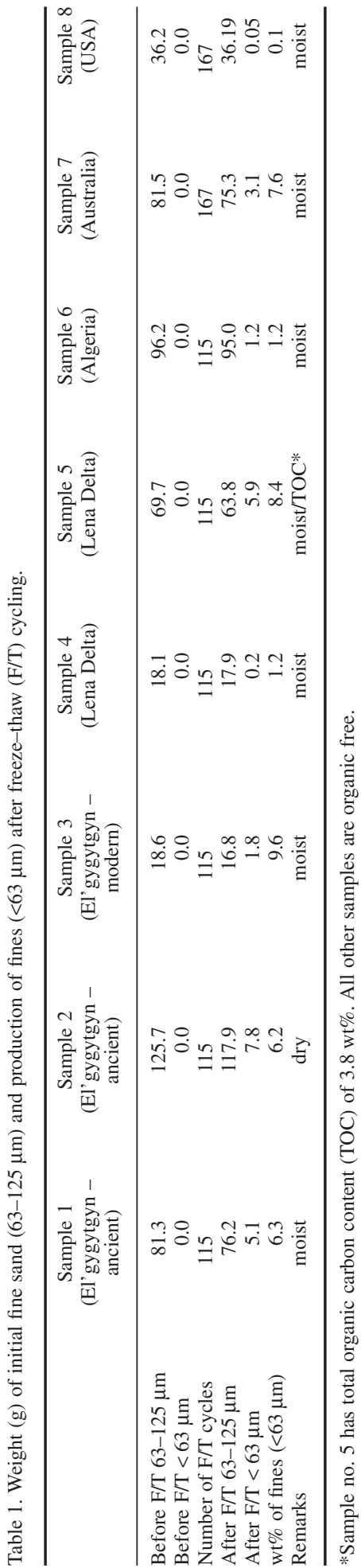

and tuffs of the Upper Cretaceous Pykarvaam formation that makes up much of the bedrock geology (Fig. 3a, b). Sample no. 4 was taken from central Arga Island fluvial deposits in the western Lena Delta, north Siberia (Fig. 3c). The sandy sediments belong to a fluvial stage of the Lena River that formed extensive floodplain formations in the Late Pleistocene. This formation is widely spread in the northwest of the modern delta. The specimen is taken from a core that penetrated through a thermokarst lake (Lake Nikolay) into the underlying fluvial Lena sediments (Schwamborn et al. 2002). Thermokarst was established soon after the Lena River abandoned the area. Sample no. 5 originates from an exposed section of fluvial sediments in the Lena Delta (Schwamborn et al. 2002). Basic mineralogic characteristics (i.e. heavy mineral composition) are the same as those found in sample no. 4 . In contrast to the sandy sediments represented by sample no. 4, this fluvial layer contains organic matter (total organic carbon $($ TOC) $=3.8$ weight $\%$ $(w t \%))$. Sample no. 6 derives from a random dune surface in the northern Algerian desert (Fig. 3d) while the reddish sample no. 7 was taken from a talus slope that flanks an isolated remnant left after the erosion of Ayers Rock in interior Australia (Fig. 3e); this mountain relict consists of Cambrian Arkose sandstone, probably representing ancient alluvial fan sedimentation. The last sample (no. 8) was taken from the foot of an alluvial fan in Death Valley, USA (Fig. 3f). Local mountain ranges there are composed of metamorphosed Palaeozoic sedimentary rock.

The assessment of relative quartz amounts is based on X-ray diffractometry (XRD) using a Philips PW1820 goniometer applying CoK $\alpha$ radiation $(40 \mathrm{kV}, 40 \mathrm{~mA})$ to non-textured pulverized samples. Feldspar is measured for reference. Feldspar is another ubiquitous mineral and was found to be less susceptible to freeze-thaw weathering than quartz in Siberian samples (Konishchev and Rogov 1993). The quartz occurrence is defined using the area below the $4.26 \AA$ peak whereas feldspar is measured by summing the $3.24+3.18 \AA$ peak areas (Vogt et al. 2001) (Fig. 4). XRD instrumental settings were chosen according to Petschick et al. (1996). Quartz grains were examined and imaged in detail using an SEM. Grain samples were washed for $10 \mathrm{~min}$ in $\mathrm{SnCl}_{2}(5 \%)$ to remove iron before they were cleaned with distilled water and doused in an ultrasonic bath $(2 \mathrm{~min})$ to remove adhering particles. Finally they were boiled in ethanol for $5 \mathrm{~min}$ before being washed again 


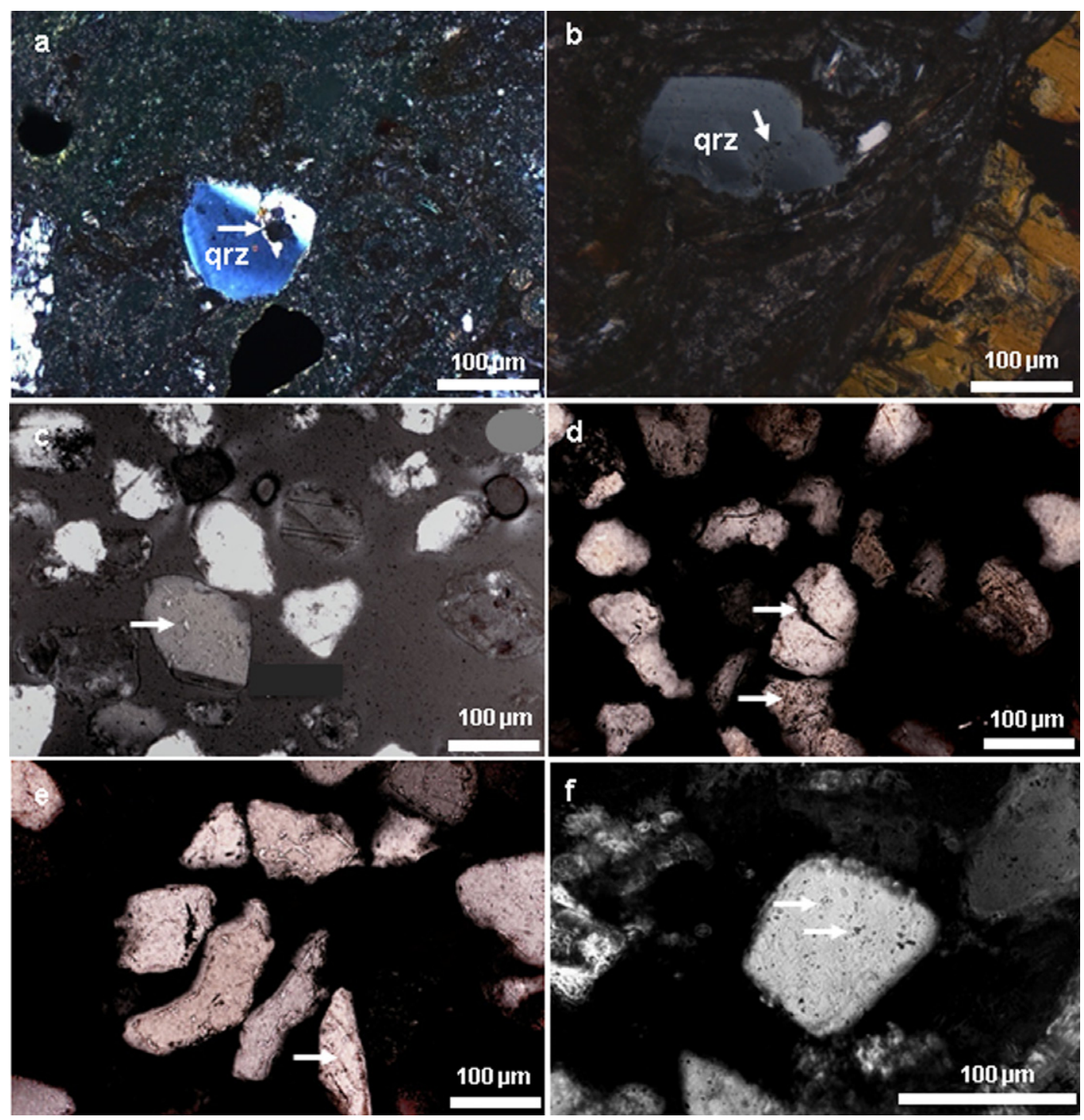

Fig. 3. Optical microscopy images displaying gas-liquid inclusions and other impurities in quartz grains that may act as weak zones under cryogenic weathering conditions. (a) Quartz grains embedded in El'gygytgyn rhyolithic host rocks (sample nos 1,2, and 3) with distinct impurities (see arrow) or (b) faintly visible inclusion trails (see arrow); (c) Lena Delta grains (sample nos 4 and 5) showing some impurities with a few bubble inclusions; (d) Algeria grains (sample no. 6) with various linear and punctuated impurities (dark areas in grains, see arrows); (e) grains from the Australia sample (no. 7) with internal sub-parallel grain boundaries (see arrow); (f) USA grains (sample no. 8) with various bubble or gas-liquid inclusions (see arrows).

(Schirrmeister 1995). Quartz grains were selected randomly under a binocular microscope; a group of 20 grains per sample was mounted on aluminium stubs and coated with gold-palladium. The grains were then examined and photographed in detail using an SEM (Ultra 55 Plus Carl Zeiss SMT). Selected samples were inspected as thin sections under the light microscope (Zeiss Axioskop) and as foils cut from quartz grains under the transmission electron microscope (TEM; FEI Tecnai ${ }^{\mathrm{TM}} \mathrm{G} 2$ F20 X-Twin with a HAADF Detector) (Frütsch 2011).

The experimental scheme comprised the following procedures. Original samples $(n=8)$ were dry- 


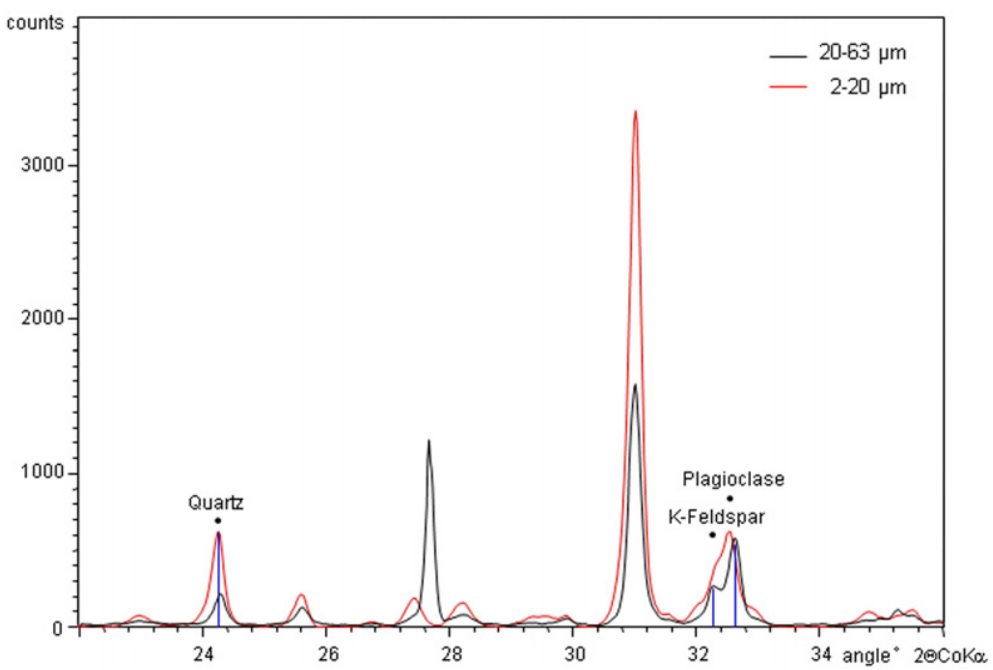

Fig. 4. Example of x-ray diffractograms comparing quartz ( $4.26 \AA)$ and feldspar $(3.18 \AA+3.24 \AA)$ in fine and coarse fractions of the same sample (here, layer at 2.50-2.54 m depth from core Lz1024). Note the higher amount of quartz in the fine fraction than in the coarse fraction.

sieved to obtain phi-stepped sand and silt fractions. Quartz and feldspar portions of a fine and a subsequent coarser fraction were semi-quantitatively measured from pulverized portions by XRD. A CWI value was calculated using Eqn (1). The fine sand fractions $(63-125 \mu \mathrm{m})$ were separated and weighed (Table 1). The fractions $<63 \mu \mathrm{m}$ were removed. The fine sand samples underwent more than 100 freeze-thaw cycles; therefore, the zero degree boundary from $-20^{\circ} \mathrm{C}$ to $+30^{\circ} \mathrm{C}$ was crossed over 200 times. This annual temperature variation is typical of a continental climate and matches the 'Siberian type' as described by Tricart (1956) and Wiman (1963). Applied in our experiment this temperature amplitude provokes grain weathering at the ground surface but not in the subsurface where thermal amplitudes significantly reduce. Each cycle usually took about $24 \mathrm{~h}$; the warming period took $16-18 \mathrm{~h}$ and the freezing period $6-8 \mathrm{~h}$. The warming peak $(2-4 \mathrm{~h})$ was longer than the cooling peak $(1 \mathrm{~h})$ and included a partial drying-up of the sample. This accounts for an average warming rate of $3.5^{\circ} \mathrm{C} \mathrm{h}^{-1}$ whereas the average cooling rate was about $7^{\circ} \mathrm{Ch}^{-1}$. The culmination of the positive and negative temperature peaks was verified using a handheld temperature probe. While seven samples were kept moist with deionized water (water was added until the samples were visually soaked with it), one sample (El'gygytgyn ancient, no. 2) was left dry (and consequently only experienced temperature cycling)
Table 2. Quartz-to-feldspar ratio (CWI) 'before' and 'after' freeze-thaw cycling.

\begin{tabular}{lccc}
\hline $\begin{array}{l}\text { Sample } \\
\text { no. }\end{array}$ & $\begin{array}{c}\left(\mathrm{Q}_{1} / \mathrm{F}_{1}\right) /\left(\mathrm{Q}_{2} / \mathrm{F}_{2}\right) \\
\text { 'before' }\end{array}$ & $\begin{array}{c}\left(\mathrm{Q}_{1} / \mathrm{F}_{1}\right) /\left(\mathrm{Q}_{2} / \mathrm{F}_{2}\right) \\
\text { 'after' }\end{array}$ & $\begin{array}{c}\text { Difference } \\
\text { 'after' - 'before' }\end{array}$ \\
\hline 1 & 1.26 & 1.26 & +0.01 \\
2 & 1.26 & 1.40 & +0.14 \\
3 & 1.36 & 1.43 & +0.07 \\
4 & 1.28 & 2.42 & +1.14 \\
5 & 1.53 & 2.35 & +0.82 \\
6 & 0.38 & 0.55 & +0.17 \\
7 & 1.73 & 1.85 & +0.12 \\
8 & 0.64 & no data & no data \\
\hline
\end{tabular}

$\mathrm{Q}_{1}=<63 \mu \mathrm{m} ; \mathrm{Q}_{2}=63-125 \mu \mathrm{m} ; \mathrm{F}_{1}=<63 \mu \mathrm{m} ; \mathrm{F}_{2}=63-125 \mu \mathrm{m}$. The resulting positive differences indicate quartz enrichment in the fine fraction after the experiment.

(Table 1). After termination of freeze-thaw cycling the samples were dry-sieved into two fractions $(63-125 \mu \mathrm{m},<63 \mu \mathrm{m})$ and weighed (Table 1). The CWI value was calculated using XRD measurements from the fine and coarse fractions (Table 2).

\section{El'gygytgyn sedimentary archives}

To compare the lake record with the modern detritus of the catchment, permafrost samples were taken from a piedmont area framing the northern shoreline. A $5 \mathrm{~m}$ drill core (core P2 in Fig. 2) recovered an accumulation of frozen ground 


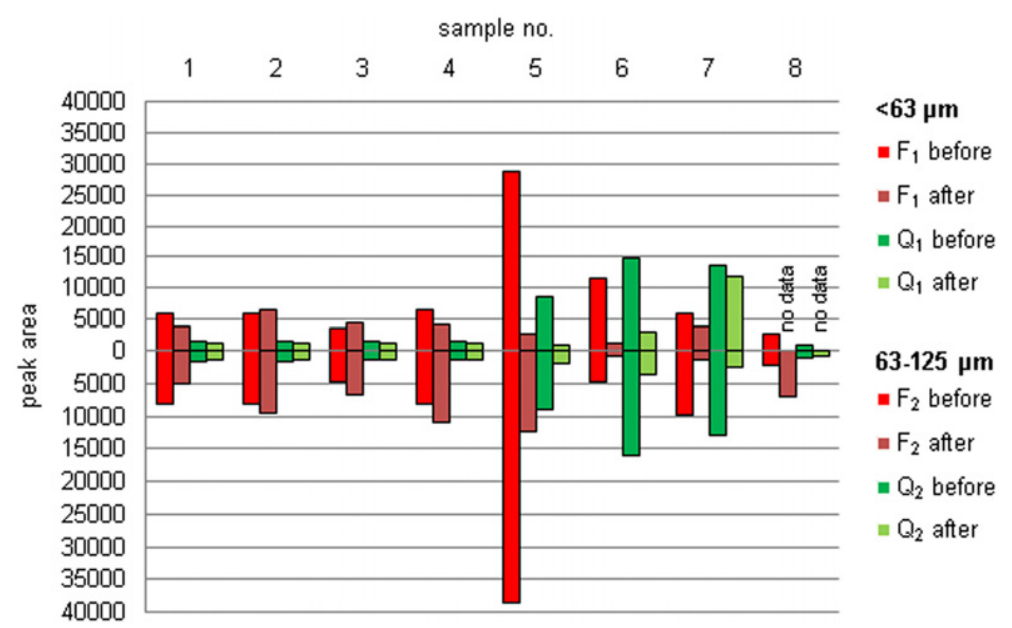

Fig. 5. Relative quartz and feldspar amounts before and after freeze-thaw cycling based on XRD measurements.

deposits that date back to 13100 years cal BP. The layers below $2.26 \mathrm{~m}$ core depth belong to the top of weathered volcanic bedrock (Schwamborn et al. 2008). The lake sediment record was cored from the centre part of the Crater Lake (core Lz1024 in Fig. 2). The sampled upper $12 \mathrm{~m}$ of the lake sediment column span the last 220000 years at millennia-scale temporal resolution (Juschus et al. 2007). These samples were prepared and measured using the same analytical approach as for the experimental material.

\section{Results}

Semiquantitative assessment of quartz

The granulometric effect of silt production after repeated freeze-thaw cycling is shown in Table 1. The experimentally produced silt $(<63 \mu \mathrm{m})$ from the eight samples varies from $0.1 \mathrm{wt} \%$ of sample no. 8 (USA) to $9.6 \mathrm{wt} \%$ of sample no. 3 (El'gygytgyn modern). For sample no. 7 (Australia) and sample no. 8 (USA) more freeze-thaw cycling was needed to crack grains; sample no. 8 was the most resistant to freeze-thaw cycling. Silt was produced at similar rates in sample nos 1 and 2 (El'gygytgyn ancient; 6.3 and $6.2 \mathrm{wt} \%$, respectively), although sample no. 1 was kept moist and sample no. 2 was kept dry. This suggests that thermal shock alone can play a considerable role. Freeze-thaw cycling broke up grains much more productively in organic-bearing sample no. 5 (Lena Delta; $8.4 \mathrm{wt} \%$ ) than in corresponding sample no. 4 without organic matter (Lena Delta; $1.2 \mathrm{wt} \%)$.
Relative quartz and feldspar amounts were assessed before and after freeze-thaw treatment in the $<63 \mu \mathrm{m}$ and $63-125 \mu \mathrm{m}$ fractions (Fig. 5) and the numerical values were inserted into Eqn (1) (Table 2). The resulting CWI values are all positive when the original fine fraction is compared with the fraction that was generated through laboratory freeze-thaw (column 'difference after before' in Table 2), indicating quartz enrichment. Remarkably, sample no. 2 (El'gygytgyn ancient), which was left dry, has more shattered quartz grains than the corresponding moist sample no. 1. However, sample no. 8 (USA) did not produce enough silt material for subsequent XRD measurements.

In the El'gygytgyn permafrost record quartz enrichment was traced downcore using samples from sediment core P2. The material from core P2 is composed of silty sand with a minor clay portion (Fig. 6). At $1.9 \mathrm{~m}$ core depth the geologic material changes from proluvial-alluvial slope deposits to underlying weathered volcanic bedrock. The CWI formula of Eqn (1) was applied using the $<63 \mu \mathrm{m}$ and $63-125 \mu \mathrm{m}$ fractions. The CWI values for a total of 27 samples range between a minimum of 0.4 and a maximum of 2.1, with an average of 1.2 . Of these 27 studied samples, 19 are placed in the zone indicative of cryogenic weathering. High and low values occur both in the weathered bedrock and in the slope deposits on top. A distinct change in the CWI range is not obvious when the facies boundary changes from weathered bedrock to the overlying slope deposits. 


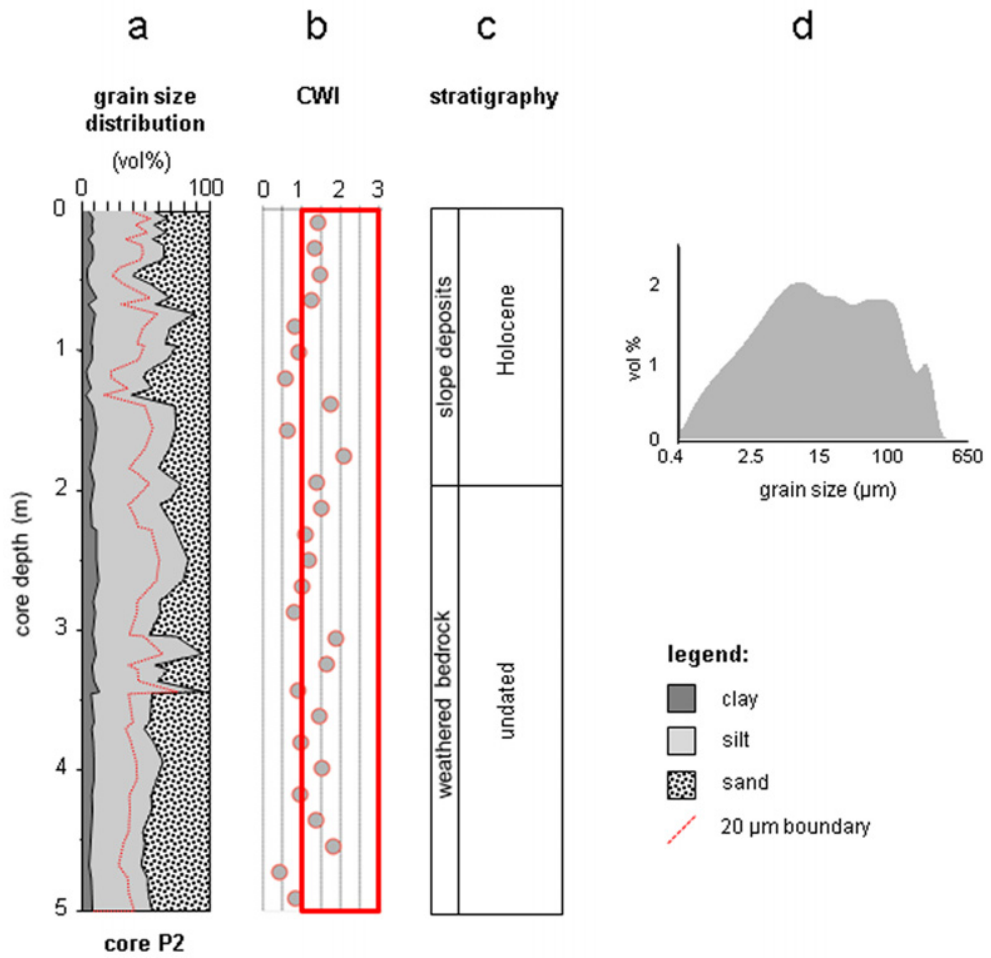

Fig. 6. Depth plot of grain-size composition (a), CWI values (b), and stratigraphy (c) from cored El'gygytgyn Crater slope deposits (core P2). (a) The dotted red line indicates the $20 \mu \mathrm{m}$ boundary for comparison with Figure 7 . The red box in (b) marks the range that is indicative of cryogenic weathering. (d) A typical polymodal grain-size curve displaying a mean at $43 \mu \mathrm{m}$ (sample at $2.65 \mathrm{~m}$ core depth).

El'gygytgyn Lake sediments in core Lz1024 consist of clayey to silty layers with a minor sand portion (Fig. 7). Laser particle sizing reveals a common major mode around $20 \mu \mathrm{m}$ (Fig. 7c). The separation of fractions for CWI calculation thus was placed at $20 \mu \mathrm{m}$, where much of the total sediment portion is found. This fine vs. coarse fraction separation is in the grain size range where quartz tends to dominate over feldspar, indicating cryogenic weathering conditions (Konishchev 1982, Fig. 1). The resulting CWI values $(n=37)$ are mostly greater than 1 ; they range between 1.0 and 2.2 with a mean of 1.5. Evidence of prominent warm periods such as the Holocene and the Eemian is not pronounced in the CWI record; both periods show relatively high (1.9, Holocene section; 1.5, Eemian section) and low (1.2, Holocene section; 1.1, Eemian section) values. More peaks with high values occur at $2.5 \mathrm{~m}$ depth (2.2), and at $7.0 \mathrm{~m}$ and $7.2 \mathrm{~m}$ depth (1.9 each). According to the age model (Juschus et al. 2007) for that core these depths correspond to $\sim 40 \mathrm{ka}$ and to $\sim 160 \mathrm{ka}$ respectively.

\section{Single grain analysis}

Optical microscopy images show that the majority of the sand-sized quartz has various grain-scale impurities. Quartz grains from El'gygytgyn bedrock are subangular to subrounded and probably originated from the comminution of more euhedrally formed crystals during ignimbrite deposition. Specimens have gas-liquid or mineral inclusions, which range from a few to tens of micrometers (Fig. 3a). Some of them are aligned in inclusion trails (Fig. 3b). Lena Delta grains (nos 4 and 5) show impurities that are a few micrometers in size and scattered across a grain (Fig. 3c). Grains from the Algeria sample (no. 6) are characterized by many microcracks or other linear streaks and point impurities that scar individual grains (Fig. 3d). Similar linear features can be observed in 


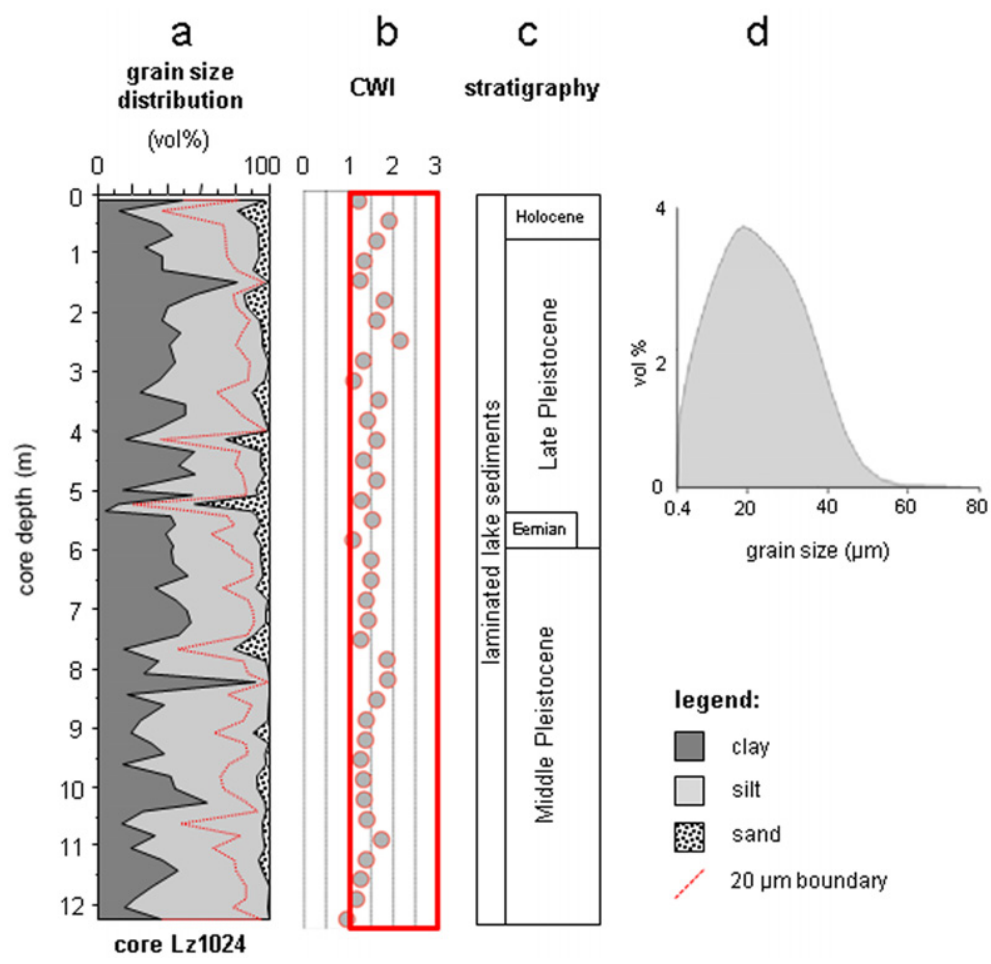

Fig. 7. Depth plot of grain-size composition (a), CWI values (b), and stratigraphy (c) from cored El'gygytgyn Crater Lake sediments (core Lz1024). (a) The dotted red line in (a) indicates the $20 \mu \mathrm{m}$ boundary for comparison with Figure 6 . The red box in (b) marks the range that is indicative of cryogenic weathering. The core covers 220,000 years (Juschus et al. 2007). (c) A typical grain-size curve of lake sediments displaying the mode at $20 \mu \mathrm{m}$ (sample at $10.64 \mathrm{~m}$ core depth).

the grains from the Australia sample (no. 7), which occasionally show parallel sub-grain boundaries (Fig. 3e). The grains from the US sample (no. 8) lack parallel scars but show various bubble or gasliquid inclusions (Fig. 3f).

El'gygytgyn grains from the experimental samples (nos 1, 2, and 3) exhibit various angular outlines and sharp fracture planes. Some of these apparently freshly split grains might have split during the freezing experiment (Fig. 8a, b). The Lena Delta grains (nos 4 and 5) mostly have subround to subangular outlines with angular and curved fracture planes (Fig. 8c, d). Some of these features seem to be fresh (Fig. 8d; see right arrow). The imagery also shows rough surfaces that suggest partial chemical dissolution (Fig. 8d; see left arrow). Grains from Algeria (no. 6) are subround to well rounded with fairly smooth surfaces. Occasionally small cracks are visible that are a few micrometers in size (Fig. 8e, f). Sediment grains from the Australian sample (no. 7) are fairly well rounded to subround (Fig. $8 \mathrm{~g}, \mathrm{~h}$ ). Grains of this sample that were collected after freeze-thaw cycling exhibit sharp edges that presumably evolved from the cryogenic splitting process (Fig. 8i, k). The US sample (no. 8) has subround to subangular grains with choncoidal fracture planes and splits on the grain surfaces. Chemical weathering and grain-to-grain drumming might have caused this micromorphology (Fig. 8m, n; see arrow).

Grains from the El'gygytgyn permafrost core P2 also have sharp edges and angular outlines (Fig. 8p). Some surfaces are scarred by various microcracks (Fig. 8q). This internal grain fracturing may initiate grain fragmentation and produce silt particles (Fig. 8r). The same brittle features can be observed in grains from El'gygytgyn Lake sediments (core Lz1024, Fig. 8s, t). The cracked surfaces are presumably inherited from the cryogenic weathering dynamics in the catchment. Other lake sediment grains show angular outlines and sharp edges, with some fresh conchoidal fracturing. Given that the generation of these broken-off chips is also related to catchment processes, this 


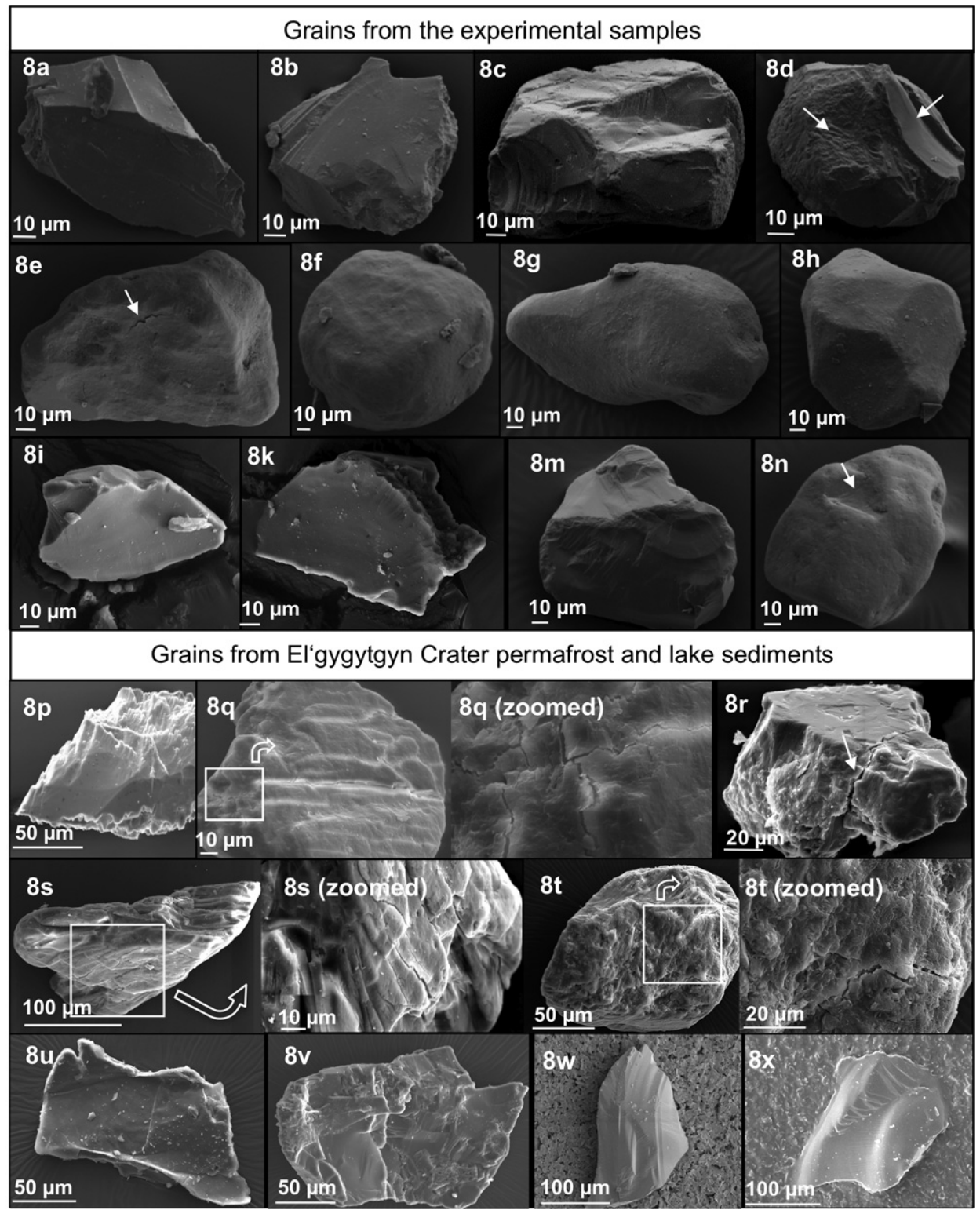

Fig. 8. SEM micrographs of quartz specimens used for the laboratory experiment and from field samples. (8a, 8b) Fragments following freeze-thaw cycling in the laboratory from the El'gygytgyn sample (nos 1-3). (8c, 8d) Grains from the Lena Delta sample (nos 4 and 5). The arrows point to chemical dissolution features and fresh fracture planes. (8e, 8f) Grains from the Algeria sample (no. 6). Note the microcrack on the surface (8e; arrow). ( $8 \mathrm{~g}, 8 \mathrm{~h}$ ) Grains from the Australia sample (no. 7). (8i, 8k) Silt-sized quartz fragments released during freeze-thaw cycling in the laboratory from the same sample. ( $8 \mathrm{~m}, 8 \mathrm{n}$ ) Grains from the US sample (no. 8). Conchoidal fracturing $(8 \mathrm{~m})$ and splits are visible ( $8 \mathrm{n}$; see arrow). (8p, 8q, 8r) El'gygytgyn particles from permafrost core P2. Note the microcracks on the surface (8q and $8 \mathrm{q}$ zoomed). These areas may act as a source of silt particles (8r; see arrow). (8s, 8t, 8u, 8v, 8w, $8 \mathrm{x}$ ) Quartz grains from El'gygytgyn lake sediments (core Lz1024) with presumably inherited cracked surfaces that have survived transport ( $8 \mathrm{~s}$ and $8 \mathrm{~s}$ zoomed; 8t and 8t zoomed). Grains with (sub-) angular outlines, sharp edges, and fresh fracture surfaces and sharp edges are associated with complete grain fracture of quartz in permafrost and short transport $(8 \mathrm{u}, 8 \mathrm{v}, 8 \mathrm{w}, 8 \mathrm{x})$. 

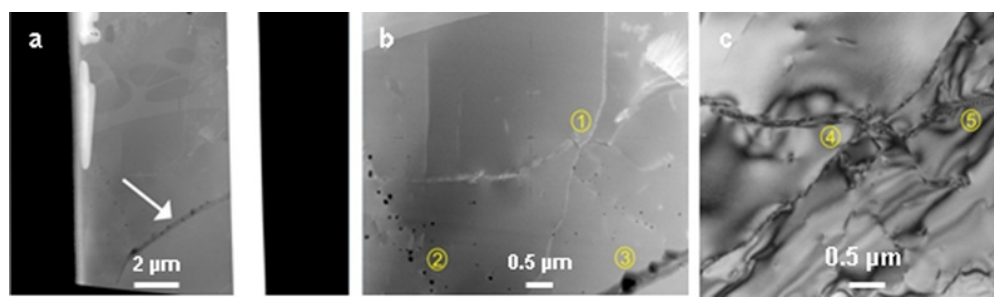

Fig. 9. TEM micrographs zooming in on a quartz grain from the El'gygytgyn samples (nos 1 to 3). (a) Overview of the foil sample that displays an inclusion trail (see arrow). (b) Enlargement of (a) in which sub-grain boundaries (1) and gas-liquid inclusions (2 and 3 ) of various sizes are visible. (c) Enlargement of (b) around (1) shows a network of dislocations at internal grain boundaries (4) and more inclusion trails (5).
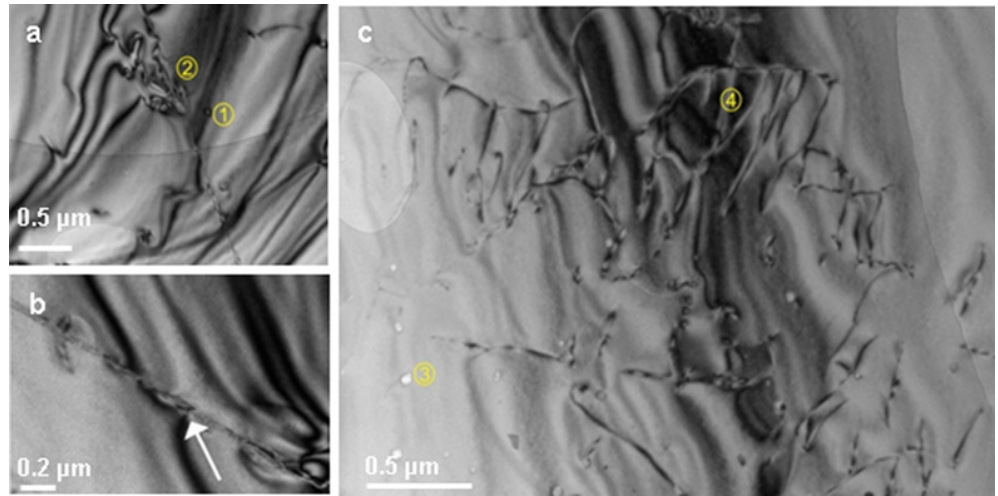

Fig. 10. TEM imagery of a Lena Delta quartz sample (nos 4 and 5). (a) Included bubbles (1) and dislocation patterns along a sub-grain boundary (2). (b) The diffraction contrast indicates a low angle sub-grain boundary (see arrow). (c) Enlarged view of an area displaying various light and dark bubble inclusions (3) and a dense dislocation pattern network (4).

suggests a short transport to the basin (Fig. 8u, v, $\mathrm{w}, \mathrm{x})$. Complementary TEM imagery shows that some quartz grains have several internal impurities (Figs 9-12). Mineralogical sub-grain boundaries are regular features within one quartz grain. Bubble trails are a common feature and gas-liquid inclusions occur to a varying extent.

\section{Discussion}

The discussion is subdivided into three parts. In the first part we discuss the experimental results in the context of a long-time interest in gaining knowledge about cryogenic weathering products. In the second part we validate the datasets from the permafrost and lake records, and in the third section we examine the consequences for studying other Quaternary records, especially those from northern environments.

\section{Freeze-thaw experiments}

Among the main driving factors considered for grain break-up are external (changing gradients in temperature and moisture levels) and internal (mineral properties of a grain) (Douglas et al. 1983). When the $0^{\circ} \mathrm{C}$ boundary is crossed, ice crystals can grow in fissures and microcracks. The rate of rock shattering was found to increase with a greater number of freeze-thaw cycles and where a greater number of planes or points of weakness occurred in a rock (Potts 1970; Lautridou and Ozouf 1982). Presumably this is also valid on the grain scale as suggested by the TEM imagery. Fluid inclusions are a common feature of quartz and are known to modify quartz grain shapes and microstructures during weak plastic deformation (Tarantola et al. 2009). We suspect that these inhomogeneities may be weak zones where quartz grains can break apart when physical stress such as freeze-thaw is applied to them.

The relationship between thermal regime, moisture content, ice crystal growth in pore space and fissures, and rock fracturing is not fully understood and this paper does not examine the actual mechanisms of grain break-up, since these are considered elsewhere (Grawe 1936; McGreevy 1981; Hall 

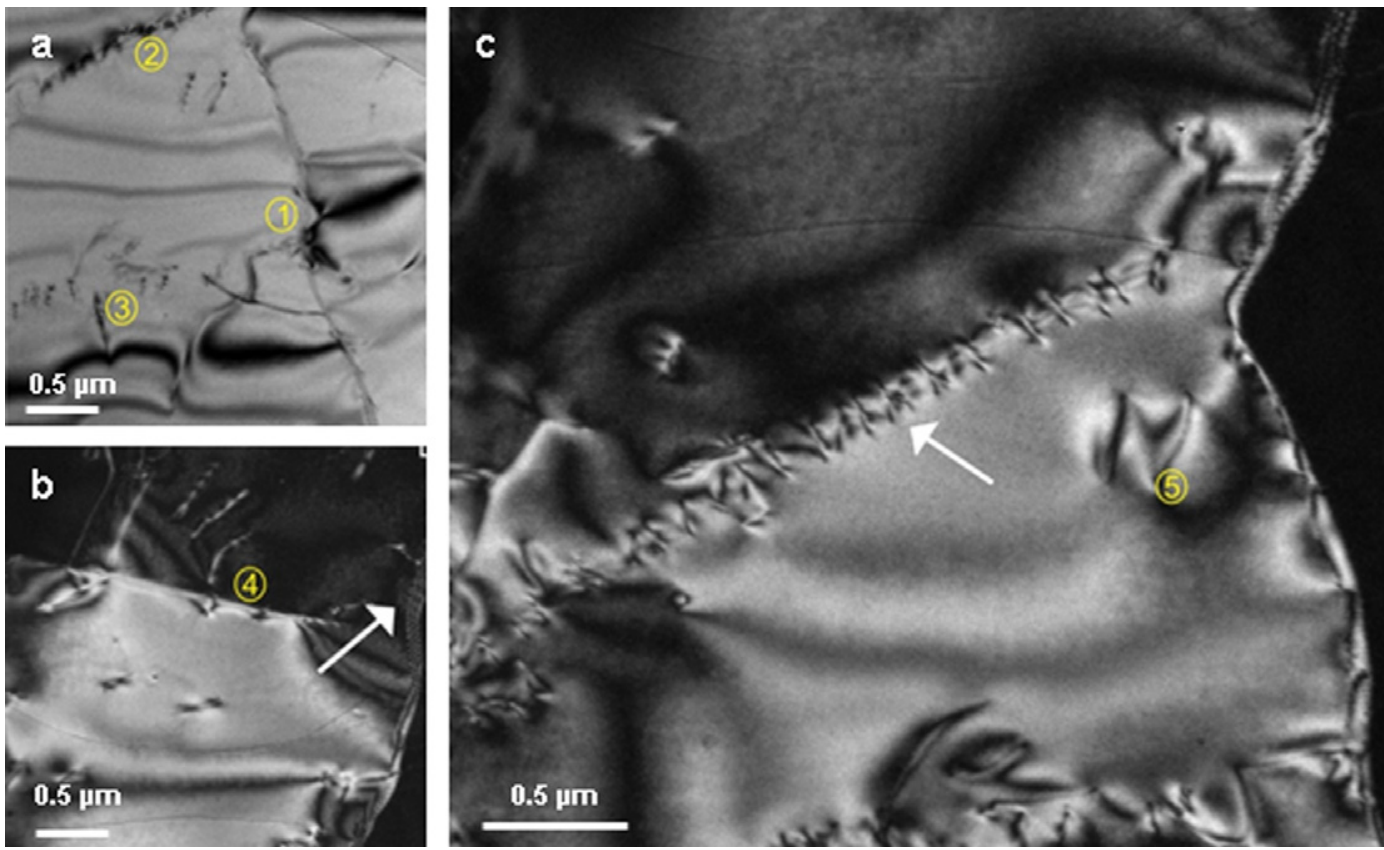

Fig. 11. TEM micrograph of quartz from the Australia sample (no. 7). (a) Two sub-grain boundaries (1 and 2) occur with various dislocations (3). (b) An inclusion trail (see arrow) is accompanied by a medium-to-dense network of dislocations located along a sub-grain boundary (4). (c) Several in-grain boundaries (see arrow) and dislocations (5).
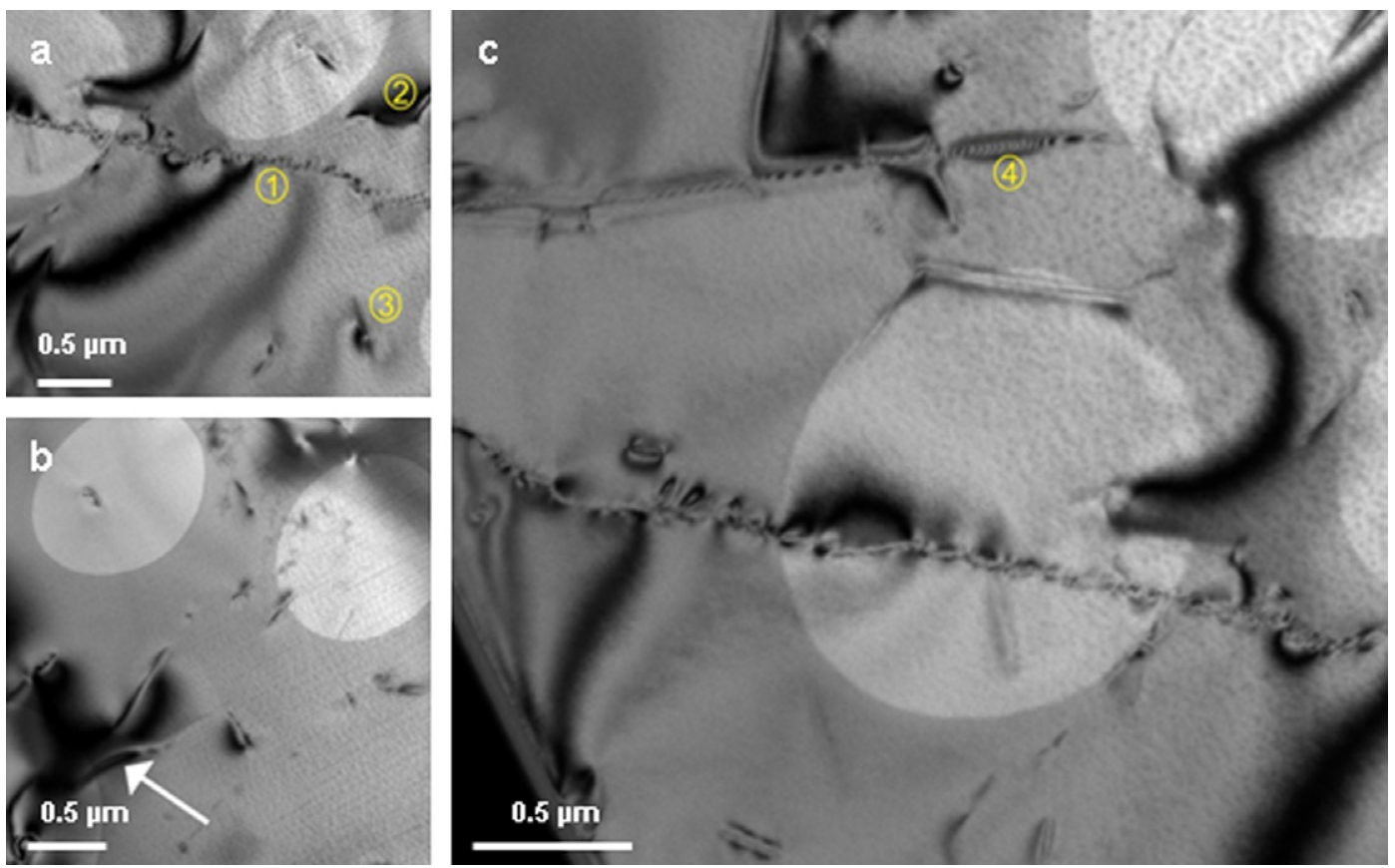

Fig. 12. TEM example of quartz in the USA sample (no. 8). (a) A sub-grain boundary (1), a dislocation creep (2), and a dislocation that occurs along an inclusion (3). (b) Various dislocation features (see arrow). (c) The diffraction contrast highlights in-grain boundaries and a small inclusion trail (4). 
and Thorn 2011). Quartz seems to be susceptible to wedging processes and weathering-derived microfractures as the SEM imagery of quartz grain surfaces suggests (Fig. 8q-t; Kowalkowski and Mycielska-Dowgiallo 1985). The fragments are characterized by sharp edges and fresh, conchoidal surfaces, indicating that they resulted from the fracturing of larger quartz masses within the rock system during weathering (White 1976).

The phase change from water to ice will build up pressure from the $9 \%$ volume expansion (Bridgman 1912) and may lead to the release of fragments from a host grain. However, whether ice-induced pressure is commonly met in nature has been questioned (Grawe 1936); naturally closed systems are rare, and in an open system pressure is relieved into the atmosphere and does not build up against confining rock. The contrasting point of view states that pressure in pore space can rise to $2200 \mathrm{MPa}$ (Yershov 1998).

Walder and Hallet (1986) point to the importance of hydration shattering, a wedging process that is initiated by adsorbed water (hydration) and its volumetric expansion. Not all water is frozen at negative temperatures (Williams and Smith 1989), and volumetric water changes in the course of temperature fluctuations can induce material shattering by means of hydration shattering. When freezing occurs, both laboratory research and theoretical models show that water migrates toward a single freezing front in rocks; similar behaviour is well known in soils (Walder and Hallet 1986). As long as water is supplied, cracks may continue to grow. We supplied water to seven out of eight samples in our freeze-thaw experiment, to reproduce what is mostly the case in the active layer; surface cracks that allow for water migration and wedging effects are obvious from the SEM imagery. This might be of importance when evaluating sample no. 5 (Lena Delta), which contained organic matter. More grains were produced from breaking in this sample than in the corresponding sample no. 4 without organics. Presumably, the organics retained a higher portion of water in this sample than in all other samples. During our experiment the thawing part of the freeze-thaw cycle often caused the other samples to become dried out, as estimated visually. This is considered to mirror natural variability, but it may, on the other hand, add wetting and drying dynamics as another particular driving factor with the potential to shatter grains, according to Dorn (2011).
Thermal stress alone, with material-dependent contraction and tensile stress can effectively break up grains as was demonstrated in Antarctica (Hall 1999; Hall and André 2003). As is obvious from the dry El'gygytgyn sample (no. 2), this process effectively triggered grain destruction in our experimental set-up. It is appropriate to point out that the experimental thermal stress may have only released fragments and flakes that were already loosened due to their prior permafrost history. Thus, the behaviour of the El'gygytgyn sample (no. 2) is not necessarily representative to other rocks. In an experiment by Minervin (1982) a corresponding experimental set-up produced a grain break-up from sand into silt sizes when applying a 'dry' temperature cycling between -10 and $50^{\circ} \mathrm{C}$ that was more than 100 times smaller in magnitude compared with a grain break-up under 'watersaturated' conditions and the same temperature cycling (in Konishchev and Rogov 1993). In a similar way, this interpretation might be applied to all the El'gygytgyn experiment samples (nos 1, 2, 3 ), which show smaller quartz enrichment in the silt after moist freeze-thaw cycling than the other samples (Table 2). This might be due to the fact that the grain composition had undergone considerable quartz destruction beforehand, since these samples have a permafrost depositional history. Such a history may reduce the potential for further quartz grain break-up, since only the more resistant grains remain. However, the greater tendency of quartz in the non-permafrost samples to break down underlines the potential of quartz weathering as a freeze-thaw indicator. The high resistance of the US sample (no. 8) to the experimental stress is associated with specific mineralogical properties of the grains that might be a result of their geologic history. The source area of the sampled alluvial fan deposits is a mountain range that consists of Palaeozoic sandstone. The sandstone has undergone orogenic folding, which might have resulted in a particular metamorphic mineral hardening.

\section{Application to permafrost and lake records}

Quartz silt is abundant in the sedimentary record, raising a long-term debate about the geomorphic mechanisms that are sufficiently energetic to produce quartz detritus (Wright 2007). In a multiple-paper effort (Konishchev 1973, 1978, 1982，1987，1997，1998，1999; Konishchev and Rogov 1984, 1993; Konishchev et al. 1988) the $10-50 \mu \mathrm{m}$ fraction was identified as the most stable 
quartz-enriched grain size produced by cryogenic break-up. This contrasts with behaviour at lower latitudes (Nesbitt et al. 1997), where quartz is commonly viewed as a mechanically and chemically resistant mineral. CWI values from core material of El'gygytgyn sedimentary permafrost and adjacent lake sediments (Figs 5 and 6) confirm that quartz-enriched fine silt is produced in the crater. Even though grains were transported on the slope, through the inlets, and into the lake, the permafrost and the lake sediment column have preserved the mineral indication of cryogenic weathering in the detritus. Presently the area has continuous permafrost and during 2003 the average air temperature was $-10.2{ }^{\circ} \mathrm{C}$ with extremes from $-40{ }^{\circ} \mathrm{C}$ to $+28^{\circ} \mathrm{C}$ (Nolan and Brigham-Grette 2007). During the Eemian, when temperatures are reconstructed to have been $2-4^{\circ} \mathrm{C}$ higher than today (Lozkhin et al. 2007), permafrost conditions and associated cryogenic weathering dynamics can be assumed. This is reflected in CWI values $>1$ at the relevant core depths. Individual down-core peaks in the P2 and Lz1024 records may be explained by various factors; differing moisture regimes during the relevant time interval, a change in water supply, or a change in the number of oscillations across the freezing point during the seasons may have had an impact on the rate of grain shattering in the catchment. Notwithstanding, the measured CWI signal may be the result of hydrodynamic sorting. Overall the CWI dataset is understood to show an integral and constant signal of cryogenic conditions and associated cryogenic weathering for the last 220000 years covered by the studied lake sediment layers. A case study of Late Pleistocene aged sediment records from New Jersey inferred an on- and offset of perennial or seasonal frost based on CWI values; here, two (possibly three) periods of coldclimate (cryogenic) conditions are identified by CWI values that change from $<1$ to $>1$ (Demitroff et al. 2007; French et al. 2009).

\section{Relevance to interpreting loess-like Quaternary deposits}

Traditionally, glacial grinding was considered to be the main process for generating silt (Smalley 1978; Seppälä 2004). Later, tropical weathering was put forward as another main producer of loess-sized quartz silt (Nahon and Trompette 1982). Wright et al. (1998) emphasized that aeolian and fluvial comminution act as other mechanisms of global quartz silt production. Subsequently, loess deposits representing the prominent Quaternary feature of silt formation have been understood to result from the interaction of a highly complex suite of environmental, lithological, tectonic, geomorphic, and topographic variables (Wright 2001). Our study provides additional evidence that where there are pervasive active-layer dynamics, quartz-rich silt is generated. Nowadays this is particularly valid for the northern permafrost landscapes, i.e. in Alaska, northern Canada, and northern Siberia (Kunitsky et al. 2002). When extrapolated into the geologic past, this idea has consequences for interpreting terrestrial sections and sedimentary archives from the north and former periglacial areas. For example, the formation of fine-grained, ice-rich Yedoma deposits in the Siberian north has a distinctive proportion of $20-40 \mu \mathrm{m}$ sized grains (Schirrmeister et al. 2011). In terms of the grain size spectrum this may point to a loess origin according to Pye (1984) and Jackson (1997). However, various processes have been put forward to explain the generation of Yedoma formations, including aeolian drift deposition to a minor extent, but also including in-situ cryogenic weathering of particles (Konishchev and Rogov 1993) and slope and fluvial wash from local sources in a polygenetic manner (Kunitsky et al. 2002; Schwamborn et al. 2002; Schirrmeister et al. 2011). The depositional area is thereby placed in a permafrost environment that is not influenced by glaciation and far away from glaciated terrain in western Beringia during the Late Pleistocene (Hubberten et al. 2004; Svendsen et al. 2004).

\section{Conclusions}

Freeze-thaw cycling is an efficient driver of quartz grain enrichment in moist silty soil in permafrost regions. Sharp-edged flakes and fragments of quartz grains with conchoidal breakage planes and microcracking of grain surfaces illustrate the destructive power of this physical weathering mechanism. When medium- to high-relief grains become fragmented due to cryogenic cracking the connection between silt production, quartz break-up, and SEM features is most obvious. In a more general way, cryogenic weathering on the grain scale is considered to be a combination of thermal shock, ice crystal growth in fissures, and hydration shattering. Care has to be taken when comparing quartz break-up in different source rocks, since in-grain impurities may be different due to a different host rock origin. Under favourable conditions the combination of silt abundance, quartz enrichment in the 
silt spectrum, and peculiar quartz grain micromorphology can be a tool for tracing cryogenic weathering in periglacial sedimentary archives. CWI values $>1$ serve as a principal indication of cryogenic weathering dynamics in quaternary records, but the CWI record may be blurred due to hydrodynamic sorting of the debris when transported off-site.

One suitable site is the El'gygytgyn Lake basin with a small catchment-to-lake ratio and a fairly uniform bedrock geology. Based on the lake sediment record it is demonstrated that there were persistent cryogenic conditions in mountainous Chukotka back to at least marine isotope stage 7 (the studied time interval). Now that the full record of the lake basin is available (Melles et al. 2011), this record offers the opportunity to trace back signals of cryogenic weathering dynamics to the upper Pliocene, presumably making it possible to obtain an age for the onset of permafrost (i.e. cryogenic) conditions in northeast Siberia.

This demonstration of in-situ creation of a loesslike grain spectrum by freeze-thaw cycling has wider implications for interpreting periglacial and geochronological datasets, especially of the Quaternary. The interpretation of the loess origin in the periglacial realm should include the potential of cryogenic weathering dynamics to produce siltsized grains.

\section{Acknowledgments}

Colleagues from DGFZ Potsdam and FU Berlin are thanked for instrumental and personal support. Dr $\mathrm{R}$. Wirth assisted with the electron microscope used for the TEM studies. A. Eulenburg and A. Förster helped with the sediment processing. We also wish to thank the El'gygytgyn science team for their support in the field and for their numerous discussions. Financial support was provided through Deutsche Forschungsgemeinschaft (grant SCHW 787/4-1). The manuscript has benefited from constructive comments by two anonymous reviewers. Candace S. O'Connor edited the English.

Georg Schwamborn, Lutz Schirrmeister and Bernhard Diekmann, Alfred Wegener Institute for Polar and Marine Research, Telegrafenberg A43, D-14473 Potsdam, Germany Email: georg.schwamborn@awi.de; lutz.schirrmeister@ awi.de; bernhard.diekmann@awi.de

Franziska Frütsch, Institut für Geologische Wissenschaften, Freie Universität Berlin, D-12249 Berlin, Germany

Email: franzifruetsch@web.de

\section{References}

Arnold, L.J. and Roberts, R.G., 2011. Paper I - Optically stimulated luminescence (OSL) dating of perennially frozen deposits in north-central Siberia. OSL characteristics of quartz grains and methodological considerations regarding their suitability for dating. Boreas, 40, 389416. doi:10.1111/j.1502-3885.2011.00209.x

Asikainen, C.A. Francus, P. and Brigham-Grette, J., 2007. Sediment fabric, clay mineralogy and grain-size as indicators of climate change since $65 \mathrm{ka}$ from El'gygytgyn Crater Lake, Northeastern Siberia. Journal of Paleolimnology, 37, 105-122.

Bateman, M.D., 2008. Luminescence dating of periglacial sediments and structures. Boreas, 37, 574-588. doi:10.1111/j.1502-3885.2008.00050.x

Belyi, V.F., 1998. Impactogenesis and volcanism of the El'gygytgyn depression. Petrology, 6, 86-99.

Belyi, V.F. and Chereshnev, I.A. (eds), 1993. The Nature of the El'gygytgyn Lake Hollow. NEISRI Magadan Magadan FEB Russian Academy of Science, 250 p. [in Russian]

Bridgman, P.W., 1912. Water, in the liquid and five solid forms, under pressure. In: Proceedings of the American Academy of Arts and Sciences, vol. 47. Boston Academy. 441-556.

Brigham-Grette, J., Melles, M., Minyuk, P. and Scientific Party, 2007. Overview and significance of a $250 \mathrm{ka}$ paleoclimate record from El'gygytgyn Crater Lake, NE Russia. Journal of Paleolimnology, 37, 1-16.

Demitroff, M., Rogov, V.V., French, H.M., Konischchev, V.N., Streletskiy, D.A., Lebedeva-Verba, M.D. and Alekseeva, V.A., 2007. Possible evidence for episodes of Late Pleistocene cryogenic weathering, southern New Jersey, Eastern USA. In: Proceedings, Volume II, Cryogenic Resources of Polar Regions. RAS, SB, Salekhard. 139-141. [English with Russian abstract]

Diekmann, B., 1990. Granulometrie und Sandkornmorphoskopie alpiner Glazialsedimente. Zentralblatt fuer Geologie und Palaeontologie Teil 1, 1989 (9/10), 14071421. [in German]

Dorn, R.I., 2011. Revisiting dirt cracking as a physical weathering process in warm deserts. Geomorphology, 135, 129-142.

Douglas, G.R., McGreevy, J.P. and Whalley, W.B., 1983. Rock weathering by frost weathering processes. In: Proceedings of the Fourth International Conference on Permafrost, vol. 2. University of Alaska, Fairbanks, Alaska. 244-248.

French, H.M., Demitroff, M., Streletskiy, D.A., Forman, S.L., Gozdzik, J., Konishchev, V.N., Rogov, V.V. and Lebedeva-Verba, M.P., 2009. Evidence for Late Pleistocene permafrost in the New Jersey Pine Barrens, Eastern USA. Earth Cryosphere, XIII (3), 17-28. [Russian with English abstract]

Froese, D.G., Westgate, J.A., Reyes, A.V., Enkin, R.J. and Preece, S.J., 2008. Ancient permafrost and a future, warmer Arctic. Science, 321, 1648.

Frütsch, F. 2011. Quartz grain weathering in a periglacial environment. Indications from SEM and TEM studies using single grain features. MSc thesis. Freie Universität, Berlin. 70 p.

Glushkova, O.Yu., 2001. Geomorphological correlation of Late Pleistocene glacial complexes of Western and 
Eastern Beringia. Quaternary Science Reviews, 20, 405417.

Grawe, O.R., 1936. Ice as an agent of rock weathering. a discussion. Journal of Geology, 44, 173-182.

Hall, K., 1999. The role of thermal stress fatigue in the breakdown of rock in cold regions. Geomorphology, 31, 47-63.

Hall, K. and André, M.-F., 2003. Rock thermal data at the grain scale. applicability to granular disintegration in cold environments. Earth Surface Processes and Landforms, 28, 823-836.

Hall, K. and Thorn, C., 2011. The historical legacy of spatial scales in freeze-thaw weathering. Misrepresentation and resulting misdirection. Geomorphology, 130, 8390.

Hallet, B., Walder, J.S. and Stubbs, C.W., 1991. Weathering by segregation ice growth in microcracks at sustained subzero temperatures. Verification from an experimental study using acoustic emissions. Permafrost and Periglacial Processes, 2, 283-300.

Harris, S.A., 1994. Chronostratigraphy of glaciations and permafrost episodes in the Cordillera of western North America. Progress in Physical Geography, 18 (3), 366395.

Hubberten, H.-W., Andreev, A., Astakhov, V.I., Demidov, I., Dowdeswell, J.A., Henriksen, M., Hjort, C., HoumarkNielsen, M., Jakobsson, M., Kuzmina, S., Larsen, E., Lunkka, J.P., Lysa, A., Mangerud, J., Moeller, P., Saarnisto, M., Schirrmeister, L., Sher, A.V., Siegert, C., Siegert, M.J. and Svendsen, J.I., 2004. The periglacial climate and environment in northern Eurasia during the last glaciation. Quaternary Science Reviews, 23, 13331357.

Jackson, J. 1997. Glossary of Geology, 2nd ed. American Geological Institute, Alexandria, Virginia. 769 p.

Juschus, O., Preusser, F., Melles, M. and Radtke, U., 2007. Applying SAR-IRSL methodology for dating fine grained sediments from Lake El'gygytgyn, northeastern Siberia. Quaternary Geochronology, 2, 187-194.

Kanevskiy, M., Shur, Y., Fortier, D., Jorgenson, M.T. and Stephani, E., 2011. Cryostratigraphy of late Pleistocene syngenetic permafrost (yedoma) in northern Alaska, Itkillik River exposure. Quaternary Research, 75, 584596.

Konishchev, V.N., 1973. Frost weathering. In: Proceedings of the 2nd International Conference on Permafrost, 13-28 July 1973, Yakutsk, USSR. Office National Academy of Sciences, Washington, DC. 176-181.

Konishchev, V.N., 1978. Mineral stability in the zone of cryolithogenesis. In: Proceedings of the 3rd International Conference on Permafrost, 10-13 July 1978, Edmonton, Canada. Part 1: English translation of twentysix of the Soviet Papers. National Research Council of Canada. Ottawa. 279-295.

Konishchev, V.N., 1982. Characteristics of cryogenic weathering in the permafrost zone of the European USSR. Arctic and Alpine Research, 14 (3), 261-265.

Konishchev, V.N., 1987. Origin of loess-like silt in Northern Yakutia, USSR. GeoJournal, 15 (2), 135-139.

Konishchev, V.N., 1997. A cryolithic method for estimating palaeotemperature conditions during formation of the Ice Complex and subaerial periglacial sediments. Earth's Cryoshere (Kryosphera Zemli), 1 (2), 23-28.
Konishchev, V.N., 1998. Relationship between the lithology of active-layer materials and mean annual ground temperature in the former USSR. In: Lewkowicz, A.G. and Allard, M. (eds.), Proceedings of the 7th International Conference on Permafrost, 23-27 June 1998, Yellowknife, Canada. Collection Nordicana. 591-594.

Konishchev, V.N., 1999. Evolution of ground temperature of Russian Arctic zone in upper Cenozoic. Earth's Cryosphere (Kryosphera Zemli), 3 (4), 39-47.

Konishchev, V.N. and Rogov, V.V., 1984. The cryogenic evolution of mineral matter (an experimental model). In: Proceedings of the 4th International Conference on Permafrost, 17-22 July 1983, University of Alaska and National Academy of Sciences. National Academy Press, Washington, DC. 656-659.

Konishchev, V.N. and Rogov, V.V., 1993. Investigations of cryogenic weathering in Europe and Northern Asia. Permafrost and Periglacial Processes, 4, 49-64.

Konishchev, V.N. Rogov, V.V. and Poklonny, S.A., 1988. Physical-chemical types of cryogenesis. In: Proceedings of the 5th International Conference on Permafrost, 2-5 August 1988. Tapir Publishers, Trondheim. 381-383.

Kowalkowski, A. and Mycielska-Dowgiallo, E., 1985. Weathering of quartz grains in the liquefied horizon of permafrost solonchaks in the arid steppe zone, Central Mongolia. Catena, 12 (2-3), 179-190.

Krbetschek, M., Gonser, G. and Schwamborn, G., 2000. Luminescence dating results on sediment sequences of the Lena Delta. Polarforschung, 70, 83-88.

Krinsley, D.H. and Doornkamp, J.C., 1973. Atlas of Quartz Sand Surface Textures. Cambridge University Press, Cambridge. $91 \mathrm{p}$.

Kunitsky, V., Schirrmeister, L., Grosse, G. and Kienast, F., 2002. Snow patches in nival landscapes and their role for the Ice Complex formation in the Laptev Sea coastal lowlands. Polarforschung, 70, 53-67.

Lacelle, D., St-Jean, M., Lauriol, B., Clark, I.D., Lewkowicz, A., Froese, D.G., Kuehn, S.C. and Zazula, G., 2009. Burial and preservation of a 30,000 year old perennial snowbank in Red Creek valley, Ogilvie Mountains, central Yukon, Canada. Quaternary Science Reviews, 28, 3401-3413.

Lautridou, J.P. and Ozouf, J.C., 1982. Experimental frost shattering. 15 years of research at the Centre de Géomorphologie du CNRS. Progress in Physical Geography, 6, 215-232. doi:10.1177/030913338200600202

Layer, P., 2000. Argon-40/argon-39 age of the El'gygytgyn impact event, Chukotka, Russia. Meteoritics and Planetary Science, 35, 591-599.

Lozkhin, A.V., Anderson, P.M., Matrosova, T.V. and Minyuk, P.S., 2007. The pollen record from El'gygytgyn Lake. implications for vegetation and climate histories of northern Chukotka since the late middle Pleistocene. Journal of Paleolimnology, 37, $135-153$.

Mahaney, W.C., 2002. Atlas of Sand Grain Surface Textures and Applications. Oxford University Press, Oxford, $237 \mathrm{p}$.

Matsuoka, N. and Murton, J., 2008. Frost weathering. Recent advances and future directions. Permafrost and Periglacial Processes, 19, 195-210.

McGreevy, J.P., 1981. Some perspectives on frost shattering. Progress in Physical Geography, 5, 56-75. 
McGreevy, J.P. and Whalley, W.B., 1985. Rock moisture content and frost weathering under natural and experimental conditions. a comparative discussion. Arctic and Alpine Research, 17 (3), 337-346.

Melles, M., Brigham-Grette, J., Glushkova, O.Yu., Minyuk, P.S., Nowaczyk, N.R. and Hubberten, H.-W., 2007. Sedimentary geochemistry of core PG1351 from Lake El'gygytgyn - a sensitive record of climate variability in the East Siberian Arctic during the past three glacialinterglacial cycles. Journal of Paleolimnology, 37, 89-104.

Melles, M., Brigham-Grette, J., Minyuk, P., Koeberl, C., Andreev, A., Cook, T., Fedorov, G., Gebhardt, C., HaltiaHovi, E., Kukkonen, M., Nowaczyk, N., Schwamborn, G., Wennrich, V. and the El'gygytgyn Scientific Party, 2011. The Lake El'gygytgyn scientific drilling project - conquering Arctic challenges through continental drilling. Scientific Drilling, 11, 29-40. doi:10.2204/iodp.sd.11. 03.2011

Meyer, H., Schirrmeister, L., Yoshikawa, K., Opel, T., Wetterich, S., Hubberten, H.-W. and Brown, J., 2010. Permafrost evidence for severe winter cooling during the Younger Dryas in northern Alaska. Geophysical Research Letters, 37, L03501. doi:10.1029/2009GL041013

Minervin, A.V., 1982. The role of cryogenic processes in forming of loess deposits. Problems of Cryolithology, 10, 41-61. Cited in: Konishchev, V.N. and Rogov, V.V. 1993. Investigations of cryogenic weathering in Europe and Northern Asia. Permafrost and Periglacial Processes, 4, 49-64. [in Russian]

Murton, J.B., 2005. Ground-ice stratigraphy and formation at North Head, Tuktoyaktuk coastlands, western Arctic Canada. A product of glacier-permafrost interactions. Permafrost and Periglacial Processes, 16, 31-50.

Murton, J.B. Peterson, R. and Ozouf, J.-C., 2006. Bedrock fracture by ice segregation in cold regions. Science, 314, 1127-1129.

Nahon, D. and Trompette, R., 1982. Origin of siltstones. glacial grinding versus weathering. Sedimentology, 29, 25-35.

Nesbitt, H.W., Fedo, C.M. and Young, G.M., 1997. Quartz and feldspar stability, steady and non-steady-state weathering and petrogenesis of siliciclastic sands and muds. The Journal of Geology, 105, 173-191.

Niessen, F., Gebhardt, C.A., Kopsch, C. and Wagner, B., 2007. Seismic investigation of the El'gygytgyn impact crater lake (Central Chukotka, NE Siberia). preliminary results. Journal of Paleolimnology, 37, 4963.

Nolan, M. and Brigham-Grette, J., 2007. Basic hydrology, limnology and meteorology of modern Lake El'gygytgyn, Siberia. Journal of Paleolimnology, 37, 17-35.

Nowaczyk, N.R., Minyuk, P., Melles, M., Brigham-Grette, J., Glushkova, O., Nolan, M., Lozkhin, A.V., Stetsenko, T.V., Anderson, P.M. and Forman, S.L., 2002. Magnetostratigraphic results from impact crater Lake El'gygytgyn, northeastern Siberia. A 300 kyr long high-resolution terrestrial paleoclimatic record from the Arctic. Geophysical Journal International, 150, 109-126.

Petschick, R., Kuhn, G. and Gingele, F., 1996. Clay mineral distribution in surface sediments of the South Atlantic. sources, transport and relation to oceanography. Marine Geology, 130, 203-229.
Potts, A.S., 1970. Frost action in rocks. some experimental data. Transaction of the Institute of British Geographers, 49, 109-124.

Pye, K., 1984. Loess. Progress in Physical Geography, 8, 176-217.

Reyes, A.V., Froese, D.G. and Jensen, B.J.L., 2010. Permafrost response to last interglacial warming. field evidence from non-glaciated Yukon and Alaska. Quaternary Science Reviews, 29, 3256-3274.

Romanovskii, N.N. and Hubberten, H.-W., 2001. Results of permafrost modelling of the lowlands and shelf of the Laptev Sea region, Russia. Permafrost and Periglacial Processes, 12, 191-202.

Schirrmeister, L., 1995. Microfabrics, grain size distribution and grain surface textures in Late Pleistocene basin sediments of Brandenburg (Northern Barnim). Zeitschrift für Geomorphologie. N.F. Supplementband, 99, 7589.

Schirrmeister, L., Grosse, G., Kunitsky, V., Magens, D., Meyer, H., Dereviagin, A., Kuznetsova, T., Andreev, A., Babiy, O., Kienast, F., Grigoriev, M., Overduin, P.P. and Preusser, F., 2008. Periglacial landscape evolution and environmental changes of Arctic lowland areas for the last 60,000 years (Western Laptev Sea coast, Cape Mamontov Klyk). Polar Research, 27 (2), 249-272.

Schirrmeister, L., Kunitsky, V., Grosse, G., Wetterich, S., Meyer, H., Schwamborn, G., Babiy, O., Derevyagin, A. and Siegert, C., 2011. Sedimentary characteristics and origin of the Late Pleistocene Ice Complex on north-east Siberian Arctic coastal lowlands and islands - a review. Quaternary International, 241, 3-25.

Schirrmeister, L., Siegert, C., Kuznetsova, T., Kuzmina, S., Andreev, A., Kienast, F., Meyer, H. and Bobrov, A., 2002. Paleoenvironmental and paleoclimatic records from permafrost deposits in the Arctic region of Northern Siberia. Quaternary International, 89, 97-118.

Schwamborn, G., Fedorov, G., Schirrmeister, L., Meyer, H. and Hubberten, H.-W., 2008. Periglacial sediment variations controlled by lake level rise and Late Quaternary climate at El'gygytgyn Crater Lake, Arctic Siberia. Boreas, 37, 55-65.

Schwamborn, G., Meyer, H., Fedorov, G., Schirrmeister, L. and Hubberten, H.-W., 2006. Ground ice and slope sediments archiving Late Quaternary paleoclimate and paleoenvironment signals at the margins of Lake El'gygytgyn impact crater, NE Siberia. Quaternary Research, 66, 259-272.

Schwamborn, G., Rachold, V. and Grigoriev, M.N., 2002. Late Quaternary sedimentation history of the Lena Delta. Quaternary International, 89, 119-134.

Seppälä, M., 2004. Wind as a Geomorphic Agent in Cold Climates. Studies in Polar Research. Cambridge University Press, Cambridge. 358 p.

Smalley, I.J., 1978. Early discoveries XXXII. P.A. Tutkovskiy and the glacial theory of loess formation. Journal of Glaciology, 20, 405-408.

Stone, D.B., Layer, P.W. and Raikevich, M.I., 2009. Age and paleomagnetism of the Okhotsk-Chukotka Volcanic Belt (OCVB) near Lake El'gygytgyn, Chukotka, Russia. Stephan Mueller Spec. Publ. Ser., 4, 243-260.

Svendsen, J.I., Alexanderson, H., Astakhov, V.I., Demidov, I., Dowdeswell, J.A., Funder, S., Gataullin, V., Henriksen, M., Hjort, C., Houmark-Nielsen, M., Hubberten, 
H.-W., Ingolfsson, O., Jacobsson, M., Kjær, K., Larsen, E., Lokrantz, H., Lunkka, J.P., Lysa, A., Mangerud, J., Matioushkov, A., Murray, A., Moeller, P., Niessen, F., Nikolskaya, O., Polyak, L., Saarnisto, M., Siegert, C., Siegert, M.J., Spielhagen, R.F. and Stein, R., 2004. Late Quaternary ice sheet history of northern Eurasia. Quaternary Science Reviews, 23, 1229-1272.

Tarantola, A., Diamond, L.W. and Stünitz, H., 2009. Modification of fluid inclusions in quartz by deviatoric stress I. experimentally induced changes in inclusion shapes and microstructures. Contrib Mineral Petrol, 160, 825843.

Thomachot, C., Matsuoka, N., Kuchitsu, N. and Morii, M., 2005. Frost damage of bricks composing a railway tunnel monument in Central Japan. field monitoring and laboratory simulation. Natural Hazards and Earth System Sciences, 5, 465-476.

Tricart, J., 1956. Etude expérimentale du problème de la gélivation. Biuletyn Peryglacjalny, 4, 285-318. [in French]

Van Hoesen, J.G. and Orndorff, R.L., 2004. A comparative SEM study on the micromorphology of glacial and nonglacial clasts with varying age and lithology. Canadian Journal of Earth Sciences, 41, 1123-1139.

Vogt, C., Knies, J., Spielhagen, R.F. and Stein, R., 2001. Detailed mineralogical evidence for two nearly identical glacial/deglacial cycles and Atlantic water advection to the Arctic Ocean during the last 90,000 years. Global and Planetary Change, 31 (1-4), 23-44. doi:10.1016/S09218181(01)00111-4

Walder, J.S. and Hallet, B., 1986. The physical basis of frost weathering. Toward a more fundamental and unified perspective. Arctic and Alpine Research, 18 (1), $27-$ 32.

Wetterich, S., Kuzmina, S., Andreev, A.A., Kienast, F., Meyer, H., Schirrmeister, L., Kuznetsova, T. and Sierralta, M., 2008. Palaeoenvironmental dynamics inferred from late Quaternary permafrost deposits on Kurungnakh Island, Lena Delta, Northeast Siberia, Russia. Quaternary Science Reviews, 27, 1523-1540.

White, S.E., 1976. Is frost action really only hydration shattering? A review. Arctic and Alpine Research, 8, 1-6.

Williams, P.J. and Smith, M.W., 1989. The Frozen Earth. Fundamentals of Geocryology. Cambridge University Press, Cambridge. 306 p.

Wiman, S., 1963. A preliminary study of experimental frost weathering. Geografiska Annaler, 45, 113-121.

Wright, J., 2001. 'Desert' loess versus 'glacial' loess. Auartz silt formation, source areas and sediment pathways in the formation of loess deposits. Geomorphology, 36, 231256.

Wright, J., 2007. An overview of the role of weathering in the production of quartz silt. Sedimentary Geology, 202, 337-351.

Wright, J., Smith, B. and Whalley, B., 1998. Mechanisms of loess-sized quartz silt production and their relative effectiveness. laboratory simulations. Geomorphology, 23, 15-34.

Yershov, E.D., 1998. General Geocryology. Studies in Polar Research. Cambridge University Press, Cambridge. English edition, $580 \mathrm{p}$.

Manuscript Received 6 Jan., 2012, revised and accepted 21 May 2012 